\title{
Is Axillary Lymph Node Clearance Indicated in Every Case of Breast Cancer?
}

\author{
SHERIF ELPRINCE SAYED, M.D.*; MAHMOUD S. AHMED, M.D.**; ANWAR A. ELSHENAWY, M.D.* and \\ MOSTAFA ISMAEL HUSSEIN, M.Sc.**
}

The Departments of Oncosurgery* and General Surgery**, Faculty of Medicine, Aswan University

\begin{abstract}
Background: Breast cancer is the most commonly diagnosed cancer and the leading cause of cancer deaths in women worldwide, accounting for $25 \%$ of total cancer cases and $15 \%$ of all cancer related mortalities.

Aim of Study: The aim of the work to find out predictors of axillary lymph nodes metastasis in breast cancer and to evaluate its significance in selecting the group of patients in whom axillary lymph nodes dissection could be avoided.

Patients and Methods: The study was including 40 patients presented with operable breast cancer at Aswan University Hospital. All patients were undergoing modified radical mastectomy or conservative breast surgery and axillary evacuation. All life stages were considered, all races were considered. All resected tissues sent to histopathological examination.

Results: In our study age is a protective factor for axillary lymph node metastasis, axillary lymph node metastasis decrease in old age, and increase with positivity of family history, mean of percentage of positive axillary lymph nodes is higher in obese patients than in normal body weight patients, tumors in upper outer quadrant have higher level of axillary lymph node metastasis followed by tumors at lower outer quadrant, tumors larger than $2 \mathrm{~cm}$ have higher incidence of axillary lymph node metastasis than tumors less than $2 \mathrm{~cm}$ in size, high grade tumours have higher incidence of axillary lymph node metastasis than low grade tumors, Her 2neu expression is an important predicator for positivity of axillary lymph nodes, mean of positive axillary lymph nodes increase in mixed lobular and ductal carcinoma more than in ductal carcinoma and this result is statistically insignificant in our study.

Conclusion: In conclusion this study reported factors that are highly predicator of axillary lymph node metastasis in breast cancer as, young age of patient, tumors larger than $2 \mathrm{~cm}$, with positive Her 2neu and positive family history, high grade tumors, tumors at upper outer quadrant, obese patient and mixed ductal and lobular carcinoma. In absence of these factors axillary node metastasis is unexpected and there axillary node dissection is not necessary and we can avoid axillary evacuation and avoid its complication.
\end{abstract}

Correspondence to: Dr. Sherif Elprince Sayed, The Department of Oncosurgery, Faculty of Medicine, Aswan University
Key Words: Axillary lymph node-Breast cancer-Estrogen receptor - HER-2.

\section{Introduction}

AXILLARY lymph node clearance remains the gold standard for evaluating metastasis which is the single most important prognostic factor for breast cancer survival rate. National guidelines state that "all invasive breast cancers should have an axillary procedures" [1].

Estrogen Receptor (ER) and Progesterone Receptor $(\mathrm{PR})$ are proteins that bind the female sex hormones estrogen and progesterone respectively. These hormones play a major role in simulating cell division in breast cells. Estrogen and progesterone bind to their respective receptors and directly stimulate genes that regulate cell division. Breast tumor cells with a positive ER and PR can be treated with hormonal therapy [2].

Human epidermal growth factor receptor 2 HER2 is a receptor protein located on the surface of breast cells. This protein binds growth factors and stimulates cell growth and division. This may result in an increased ability to grow and spread. These types of breast cancer can be treated with a type of targeted therapy [3].

Several nomograms and models have been created to help clinicians to estimate risks that a patient has axillary lymph node metastasis at time of their breast cancer diagnosis [4]

\section{Patients and Methods}

The study was including 40 patients presented with operable breast cancer at Aswan University Hospital in the duration from Abril 2018 up to 
August 2019. All patients were undergoing modified radical mastectomy or conservative breast surgery and axillary evacuation. All life stages were considered, all races were considered. All resected tissues sent to histopathological examination.

Certain factors related to the primary tumor recorded including: (Tumor size, histologic type, tumor grade, body mass index, family history and positivity or negativity for estrogen, progesterone receptors and HER2neu).

Pre-operative assessment of patients includes:

-Detailed history: (Personal history, present history, past history and family history that include first degree relatives like mother and sister).

- Examination:

\section{1- General examination:}

- General condition and appearance.

- Vital signs: Pulse, temperature, respiratory rate, blood pressure.

- Systemic examination: Chest, heart, lung, limbs, bone, muscle, movement and lymph nodes.

2- Local examination: It included inspection and palpation of breasts and chest wall as well as the axillary and supraclavicular lymph nodes.

\section{- Investigation:}

- Routine laboratory investigation.

- Imaging studies: Mammography and ultrasound of the breast, chest X-ray, pelviabdominal ultra-sound and bone scan.

- Histopathology: All patients were diagnosed by Tru-cut biopsy from the breast.

\section{Operative technique:}

Anesthesia: General anesthesia is the method of choice. Long-acting muscle relaxants not given to allow intra operative nerve identification.

\section{Modified radical mastectomy: \\ Procedure:}

Step 1: An incision was chosen which includes excision of the nipple-areolar complex and incorporates any previous biopsy incision. Remaining skin may be spared.

Step 2: Skin flaps were raised sharply with a cautery, extending superiorly to the clavicle, medially to the lateral border of the sternum, inferiorly to the superior aspect of the rectus sheath, and laterally to the latissimus dorsi muscle.
Step 3: The pectoralis major fascia was incised, controlling internal mammary perforators (medially) with ties.

Step 4: The latissimus dorsi muscle edge was followed superiorly along its anterior surface. As the muscle becomes tendinous, the axillary vein was encountered crossing superior to it.

Step 5: Dissection was then continued along the axillary vein about $5 \mathrm{~mm}$ inferior to the vein, again in a layer-by-layer, lateral-to-medial fashion from the latissimus muscle to the chest wall.

Step 6: The thoracodorsal bundle was come into view during the dissection along the inferior edge of the axillary vein. The nerve was usually slightly posteromedial to the vein of the latissimus dorsi muscle and preserved.

Step 7: The tissue remaining between the nerves was swept inferiorly with an open gauze sponge over the first two fingers.

Step 8: The thoracodorsal bundle was followed inferiorly along its anterior surface, clipping and dividing small vein branches as they arise.

Step 9: When the thoracodorsal bundle turns and dives into the latissimus dorsi muscle and the long thoracic nerve turns and enters the chest wall, the remainder of the specimen was removed by electrocautery where it remains attached inferolaterally.

Step 10: A round Jackson-Pratt drain was placed beneath the inferior skin flap and brought out through a separate stab incision. A second drain was placed into the axilla.

Step 11: The deep dermal layer was closed with interrupted 3-0 absorbable sutures and the skin with running subcuticular 4-0 absorbable suture.

\section{Post-operative:}

The Jackson-Pratt drains were stripped periodically and output recorded. The drains removed when output was less than 30cc/day for 2 days. Range-of-motion exercises should be initiated about 2 days after surgery.

\section{Statistical analysis:}

Recorded data were analyzed using the statistical package for social sciences, version 22.0 (SPSS Inc., Chicago, Illinois, USA). Quantitative data were expressed as mean \pm Standard Deviation (SD). Qualitative data were expressed as frequency and percentage. 


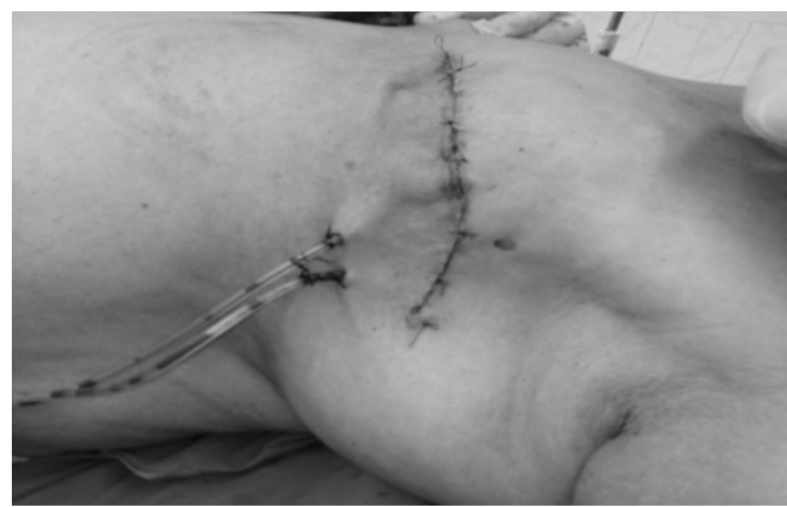

Fig. (1): Illustrating wound post modified radical mastectomy.

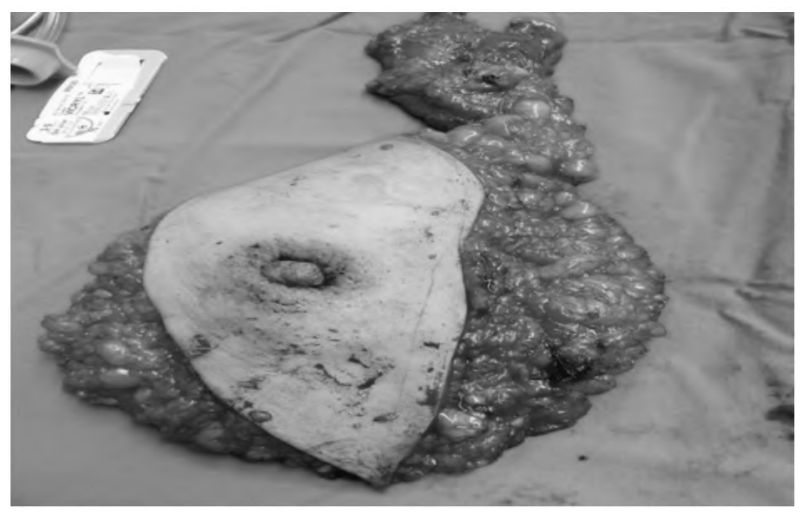

Fig. (2): Illustrating mastectomy specimen.

\section{Results}

Relation between age (years) and percentage of +ve axillary L.Ns.:

This study include 40 patient 8 patient were less than 45 years old and 32 patient more than 45 years old, we found that patient less than 45 years old have high percentage of positive axillary lymph node than patient more than 45 years old and the result is statistically significant ( $p$-value 0.013 ).

Relation between BMI $\left(\mathrm{Kg} / \mathrm{m}^{2}\right)$ and percentage of +ve axillary L.Ns.:

This study include 40 patient there were 16 patient with body mass index less than 25 and this is the normal body weight and 24 patient with body mass index more than 25 and these are obese patient we found that obese patient have high percentage of positive axillary lymph node than normal body weight patient and the result is statistically significant ( $p$-value 0.042).

\section{Relation between Her2neu and percentage of} +ve axillary L.Ns.:

This study includes 40 patient 32 patient Her2neu at there tumor was negative and 8 positive, we found that positive tumors have higher incidence of positive axillary lymph nodes than negative this statistical result is significant ( $p$-value 0.001 ).

Relation between size $(\mathrm{cm})$ and percentage of +ve axillary L.Ns.:

This study include 40 patient 4 patients of tumor size $2 \mathrm{~cm}$ or less and 36 more than $2 \mathrm{~cm}$ in size, we found that tumor more than $2 \mathrm{~cm}$ have higher incidence of positive axillary lymph nodes than tumors less than $2 \mathrm{~cm}$ this result is statistically significant (p-value 0.01).

Relation between grade and percentage of $+v e$ axillary L.Ns.:

This study have 40 patient 36 patient have tumors of low grad and 4 patient high grade, we found that high grade have higher incidence of positive axillary lymph nodes and this result is statstically significant ( $p$-value 0.01$)$.

This study have 40 patient 20 patient have tumors of histopathological type infiltrating ductal carcinoma, 12 invasive duct carcinoma, and 8 invasive mixed (ductal and lobular), we found that mixed type have higher incidence of positive axillary lymph nodes than others and this result is statistically insignificant ( $p$-value 0.122 ).

This study include 40 patient there are 12 patient have tumor at upper outer quadrant of breast, 8 at lower outer quadrant 8 at upper inner quadrant 4 at lower inner quadrant and 8 retroareolar, we found the higher incidence of positive axillary lymph nodes occur with upper outer quadrant followed by lower outer quadrant and the result is significant ( $p$-value 0.001).

Table (1): Relation between histopathological type and percentage of +ve axillary L.Ns.

\begin{tabular}{lcccccc}
\hline & \multicolumn{3}{c}{$\begin{array}{c}\text { Histopathological } \\
\text { type }\end{array}$} & & \multicolumn{2}{c}{$\begin{array}{c}\text { Kruskal-Wallis } \\
\text { test }\end{array}$} \\
\cline { 2 - 4 } Positive & $\begin{array}{c}\text { Infiltrating duct } \\
\text { carcinoma } \\
(\mathrm{n}=20)\end{array}$ & $\begin{array}{c}\text { Invasive duct } \\
\text { carcinoma } \\
(\mathrm{n}=12)\end{array}$ & $\begin{array}{c}\text { Invasive mixed (duct \& } \\
\text { lobular) carcinoma } \\
(\mathrm{n}=8)\end{array}$ & & $\begin{array}{c}p- \\
\text { value }\end{array}$ & Sig. \\
\hline Mean \pm SD & $1.6 \pm 1.9$ & $1.67 \pm 1.3$ & $4.5 \pm 3.74$ & & 0.122 & NS \\
Median & 1 & 2 & 4.5 & & \\
Range & $(0-5)$ & $(0-3)$ & $(1-8)$ & & & \\
\hline
\end{tabular}


Table (2): Relation between tumor site and percentage of +ve axillary L.Ns.

\begin{tabular}{|c|c|c|c|c|c|c|c|}
\hline \multirow{2}{*}{$\begin{array}{l}\text { Positive } \\
\text { ALN }\end{array}$} & \multicolumn{5}{|c|}{$\begin{array}{l}\text { Tumor } \\
\text { site }\end{array}$} & \multicolumn{2}{|c|}{$\begin{array}{c}\text { Kruskal-Wallis } \\
\text { test }\end{array}$} \\
\hline & $\begin{array}{c}\text { UOQ } \\
(n=12)\end{array}$ & $\begin{array}{l}\mathrm{LOQ} \\
(\mathrm{n}=8)\end{array}$ & $\begin{array}{c}\text { UIQ } \\
(\mathrm{n}=8)\end{array}$ & $\begin{array}{c}\text { LIQ } \\
(n=4)\end{array}$ & $\begin{array}{c}\text { Retro } \\
\text { areolar }(n=8)\end{array}$ & $p$-value & Sig. \\
\hline Mean $\pm S D$ & $4.5 \pm 2.37$ & $1 \pm 1.07$ & $1 \pm 0$ & $1 \pm 0$ & $0 \pm 0$ & $<0.001 *$ & S \\
\hline Median & 4 & 1 & 1 & 1 & 0 & & \\
\hline Range & $(2-8)$ & $(0-2)$ & $(1-1)$ & $(1-1)$ & $(0-0)$ & & \\
\hline
\end{tabular}

Post-hoc of Kruskal-Wallis test was significant between:

UOQ group Vs. (LOQ and retro areolar groups).

\section{Discussion}

In our study, age is a protective factor against axillary lymph node metastasis. Axillary lymph node metastasis decrease in old age. Explanation of this that Breast cancer is a hormone-related disease, and the hormone levels of the body decrease change with age Mamounas et al., [5]. Breast cancer has a somewhat different biologic behavior in older patients versus younger patients. Advancing age is associated with more favorable tumor biology and the most important that the number of tumorinfiltrating lymphocytes in breast cancer decreases with age Zavagno et al., [6] this result regarding relation between age of patient and percentage of positive axillary lymph nodes agreed with the result of Ling and Li-Zhang [7], Jamal et al., [8] and Chisthi and Kuttanchettiyar [9] in their studies.

In this study mean of percentage of positive axillary lymph nodes is higher in obese patients than in normal body weight patients. This can be explained that in obese women, aromatization of androstenedione in the adipose tissue is the major source of estrogen production and this may result in enhanced tumor growth. Furthermore, obese and postmenopausal patients show decreased levels of sex hormone-binding globulin, thus increasing free estradiol available to target tissues Potischman et al., [10] and this result is agreed with study by Chisthi and Kuttanchettiyar [9]. In the Porter and colleagues study, an elevated risk of lymph node metastasis in association with increasing BMI was found Porter et al., [11]

In a study of 176 node-positive breast cancer patients, a significantly increased risk of early axillary metastasis was found in the obese group Daniell et al., [12], Schapira and colleagues also showed more common axillary lymph node involvement in obese postmenopausal patients than in leaner cases with unfavorable prognosis [13].

Keskin in his study show no relation between body mass index and axillary lymph node metastasis and this not agreed with our study Keskin et al., [14] this difference may be due to small number of obese patient in there study.

In this study estrogen and progesteron receptor negative tumors has more axillary lymph node metastasis than estrogen and progesterone positive patients but in our statistical result are not significant this can be explained that ER and PR receptor have role in transcriptional activation of the genes required for the tumor growth Aitken and Osman [15] and Arisio et al., [16] agreed with our study but Chua et al., [17], Ling and Li-Zhang [7] and Jamal et al., [8] not agreed with our study.

In this study Her 2neu expression is an important predicator for positivity of axillary lymph nodes and explanation of this that Her 2neu is a member of the epidermal growth factor receptor family that is involved in the regulation of cell growth, proliferation and differentiation of tumor cells Positive expression in cancer cells indicates strong proliferative ability, rapid disease progression it is therefore an important early indicator of poor prognosis and metastasis of breast cancer. Chisthi and Kuttanchettiyar [9] and Elsayed et al., [18] agreed with our study but Almasri et al., [19] in there study say that Her 2neu expression not significant at axillary lymph node metastasis this difference may be due to study of Her 2neu expression was univariate analysis but in there study it was multivariate analyses.

In this study mean of positive axillary lymph nodes increase in mixed lobular and ductal carcinoma more than in ductal carcinoma and the explanation of this statistical result that It has been demonstrated that loss of expression of the cellcell adhesion molecule E-cadherin in ILC may decrease adhesiveness of cells and facilitate this type of infiltration [20]. The morphologic features of lobular carcinoma differ from those of ductal carcinoma. ILC is characterized by small, round cells that are bland in appearance and have scant cytoplasm, which infiltrate the stroma in single file and surround benign breast tissues in a targeted 
manner [21]. Infiltration typically does not destroy anatomic structures or incite a substantial connective tissue response. By virtue of their distinctive growth pattern and biology, lobular carcinomas often fail to form distinct masses that can easily be diagnosed by palpation or mammography. This can make early diagnosis challenging [22]. Lobular carcinomas may have increased risk for multifocal and multicentric distribution, bilaterality and for metastatic spread to axillary lymph node and distant metastasis [23]. But in our study this statistical result is not significant.

In this study statistical analysis reported that incidence of axillary lymph node metastasis increases in tumor grade 3 than in tumor grade 2 , explanation of this, that grade 3 tumors cells tend to be rapid growing which may indicate that the invasive tumor growth cycle is shorter and this fasten axillary node metastasis [24]. Some studies agreed with this as Jamal et al., [8] and other studies not agreed with this in statistical analysis of their study as Chisthi and Kuttanchettiyar [9]. This difference of results may be due to very less number of patients with grade 3 pathologies.

\section{Conclusion:}

In conclusion this study reported factors that are highly predicator of axillary lymph node metastasis in breast cancer as, young age of patient, tumors larger than $2 \mathrm{~cm}$, with positive Her $2 \mathrm{neu}$ and positive family history, high grade tumors, tumors at upper outer quadrant, obese patient and mixed ductal and lobular carcinoma. In absence of these factors axillary node metastasis is unexpected and there axillary node dissection is not necessary and we can avoid axillary evacuation and avoid its complication.

\section{References}

1- MICHIE S., ATKINS L. and WEST R.: The Behaviour Change Wheel: A Guide to Designing Interventions. (1 st ed.). Silverback Publishing: London. www. behaviourchangewheel.com, 2014.

2- MORROW M.: Management of the Node-Positive Axilla in Breast Cancer in 2017: Selecting the Right Option. JAMA Oncol., 4 (2): 250-1, 2018.

3- PARK K.U. and CAUDLE A.: Management of the Axilla in the Patient with Breast Cancer. Surg. Clin. North Am., 98 (4): 747-60, 2018.

4- OULDAMER L., ARBIOND F., BALAGNY A., et al.: Validation of a breast cancer nomogram for predicting nonsentinel node metastases after minimal sentinel node involvement: Validation of the Helsinki breast nomogram. Breast, 22 (5): 787-92, 2013.

5- MAMOUNAS E.P.: Age and lymph node status in breast cancer: Not a straightforward relationship. J. Clin. Oncol., 27: 2900-1, 2009.
6- ZAVAGNO G., MEGGIOLARO F. and PLUCHINOTTA A.: Influence of age and menopausal status on pathologic and biologic features of breast cancer. Breast, 9: 320-8, 2000.

7- LING L. and LI-ZHANG C.: Factors Influencing Axillary Lymph Node Metastasis in Invasive Breast Cancer. Asian Pac. J. Cancer Prev., 13 (1): 251-4, 2012.

8- JAMAL K.A.: Factors Predicting Positive Axillary Lymph Nodes Metastasis in Primary Breast Cancer in Women Anb. Med. J., 10 (2): 62-8, 2012.

9- CHISTHI M.M. and KUTTANCHETTIYAR K.G.: Clinico -pathological profile of axillary lymph node status in early breast carcinoma-a tertiary care centre experience. Int. Surg. J., 3: 776-80, 2016.

10- POTISCHMAN N., SWANSON C.A., SIITERI P., et al.: Reversal of relation between body mass and endogenous estrogen concentrations with menopausal status. J. Natl. Cancer Inst., 88: 756-8, 1996.

11- PORTER G.A., INGLIS K.M., WOOD L.A., et al.: Effect of obesity on presentation of breast cancer. Ann. Surg. Oncol., 13: 327-32, 9, 2006.

12- DANIELL H.W., TAM E. and FILICE A.: Larger axillary metastases in obese women and smokers with breast cancer an influence by host factors on early tumor behav ior. Breast Cancer Res. Treat., 25: 193-2010, 1993.

13- SCHAPIRA D.V., KUMAR N.B., LYMAN G.H., et al.: Obesity and body fat distribution and breast cancer prognosis. Cancer, 67: 523-8, 1991.

14- KESKIN O., AKSOY S., BABACAN T., et al.: Obesity and nodal status in breast cancer JBUON, 18 (4): 826-8, 2013.

15- AITKEN E. and OSMAN M.: Factors Affecting Nodal Status in Invasive Breast Cancer: A Retrospective Analysis of 623 Patients. The Breast Journal, 16 (3): 271-8, 2010.

16- ARISIO R., SAPINO A., GASSONI P., et al.: What modifies the relation between tumour size and lymph node metastases in T1 breast carcinomas? J. Clin. Pathol., 53: 846-50, 2000.

17- CHU K.U., TURNER R.R., HANSEN N.M., et al.: Do all patients with sentinel node metastasis from breast carcinoma need complete axillary node dissection? Ann. Surg., 229: 536-41, 1999.

18- ELSAYED M.A., AHMED R.H.A. and AYMAN M.A.A.: Correlation of Breast Cancer Subtypes Based on ER, PR and HER2 Expression with Axillary Lymph Node Status. Cancer and Oncology Research, 2 (4): 51-7, 2014.

19-ALMASRI N.M. and AL HAMAD M.: Immunohistochemical evaluation of human epidermal growth factor receptor 2 and estrogen and progesterone receptors in breast carcinoma in Jordan. Breast Cancer Res., 7: 598-604, 2005.

20- LEHR H.A., FOLPE A., YAZIJI H., et al.: Cytokeratin 8 immunostaining pattern and E-cadherin expression distinguish lobular from ductal breast carcinoma. Am. J. Clin. Pathol., 114: 190-6, 2000.

21- LI Q., WANG L. and WU H.: Controlled study of traditional ultrasound and ultrasound elastography on the 
diagnosis of breast masses. Ultrasound Q., 31 (4): 2504, 2016.

22- YEATMAN T.J., CANTOR A.B., SMITH T.J., et al.: Tumor biology of infiltrating lobular carcinoma. Implications for management. Ann. Surg., 222: 549-59, 1995.

23- TOIKKANEN S., PYLKKANEN L. and JOENSUU H.:
Invasive lobular carcinoma of the breast has better shortand long-term survival than invasive ductal carcinoma. Br. J. Cancer, 76: 1234-40, 1997.

24- LIU S., DONTU G. and MANTLE I.D.: Hedgehog signaling and Bmi-1 regulate self-renewal of normal and malignant human mammary stem cells. Cancer Res., 66: 6063-71, 2006.

\section{هل يتم إزالة الغدد الليمفاوية فآ كل حالة مصابة بسرطان الثدى:}

المقدمة: يعتبر سرطان الثىى آكثر آنقاع السرطان تثخيصاً والسبب الرئيسى لوفيات السرطان لدى النساء فى جميع آنحاء العالم، حيث

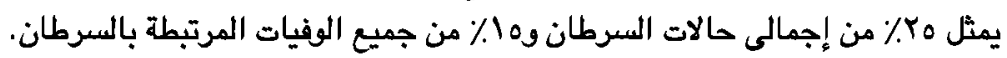

الهدف من الرسالة: الهدف من دراستنا هو إنقاذ بعض المرضى الذين يعانون من سرطان الثىى عن طريق تقييم العوامل التي تتبباً بإصابة

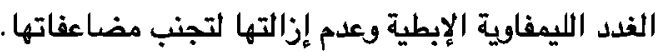

المرضى وطرق البحث: شملت الدراسة آريعين مريضاً آصيبيا بسرطان الثدى فى مستشفى آسوان الجامعى فى الفترة من ه ه آبريل

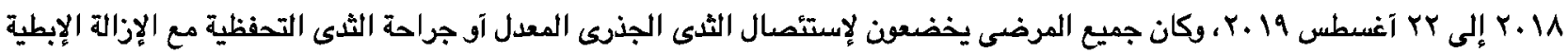

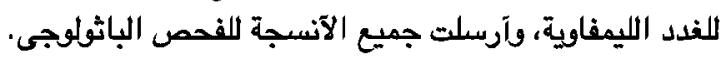

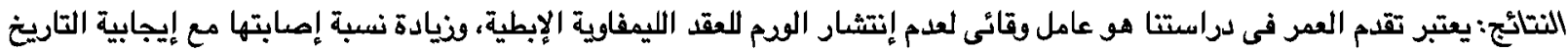

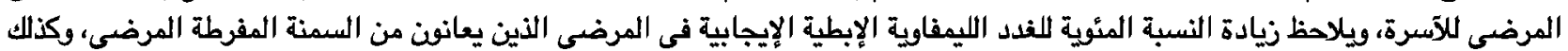

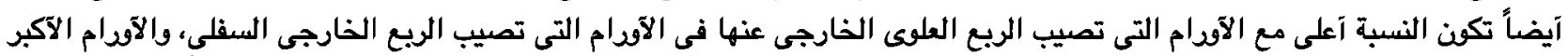

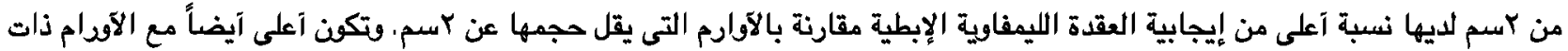
الدرجة العالية، وتعتبر مستقبلات الهرمونات هير ب نيو عامل مهم لإيجابية الفدل الليمفاوية الإبطية.

الخلاصدة: ذكرت هذه الدراسة العامل التى تعتبر شديدة التوقع لإصابة العقد الليمفاوية الإبطية فى حالات سرطان الثَى وهى مثل صغر

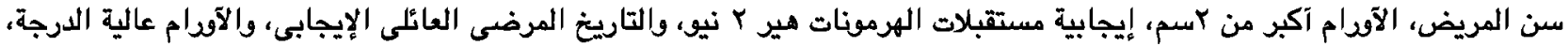
والآودام التى تصيب الريع العلوى الخارجى، المريى الذيى يعانون من السمنة المفرطة. في غياب هذه العوامل، فإن إنتثار الودم للغدد الليمفاوية الإبطية هو آمر غير متوقع وبالتالى فإنه يمكن تجنب الإخلاء الإبطى وتجنب

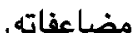

